University of Wollongong

Research Online

Faculty of Business - Papers (Archive)

Faculty of Business and Law

2013

Modelling real-time online information needs: A new research approach for complex consumer behaviour

Robert G. Grant

University of Wollongong, rgrant@uow.edu.au

Rodney J. Clarke

University of Wollongong, rclarke@uow.edu.au

Elias Kyriazis

University of Wollongong, kelias@uow.edu.au

Follow this and additional works at: https://ro.uow.edu.au/buspapers

Part of the Business Commons

Research Online is the open access institutional repository for the University of Wollongong. For further information contact the UOW Library: research-pubs@uow.edu.au 


\title{
Modelling real-time online information needs: A new research approach for complex consumer behaviour
}

\author{
Abstract \\ A major challenge for online vendor website operations is serving information that meets visitor needs at \\ a given point in their purchase process. The problem arises from the complexity of human behaviour as \\ well as changing needs with the evolution of consumer knowledge and skills through the purchase \\ process. The most difficult element however is determining the effects of information provided on the site \\ as well as from other sources that the consumer may access and anticipating resulting consumer needs. \\ This paper discusses the contributions and limitations of current modelling techniques and utility studies \\ of online consumer information to model consumer needs in real time. An alternative basis for real time \\ customer need appraisal is proposed using clickstream and customer input data combined with online \\ information utility to enable more effective information serving. This requires further academic research \\ and changes in practitioner online marketing operations.

\section{Keywords} \\ era2015 \\ Disciplines \\ Business

\section{Publication Details} \\ Grant, R. G., Clarke, R. J. \& Kyriazis, E. (2013). Modelling real-time online information needs: A new \\ research approach for complex consumer behaviour. Journal of Marketing Management, 29 (7-8), \\ 950-972.
}


Modelling real-time online information needs: A new research approach for complex consumer behaviour

\author{
Robert Grant \\ Rodney J. Clarke \\ Elias Kyriazis \\ School of Management and Marketing \\ University of Wollongong \\ Northfields Avenue \\ Wollongong NSW 2522
}

Australia

Correspondence: Robert Grant

e-Mail: rgrant@uow.edu.au

Phone: +612 42214490 


\begin{abstract}
A major challenge for online vendor website operations is serving information that meets visitor needs at a given point in their purchase process. The problem arises from the complexity of human behaviour as well as changing needs with the evolution of consumer knowledge and skills through the purchase process. The most difficult element however is determining the effects of information provided on the site as well as from other sources that the consumer may access and anticipating resulting consumer needs. This paper discusses the contributions and limitations of current modelling techniques and utility studies of online consumer information to model consumer needs in real time. An alternative basis for real time customer need appraisal is proposed using clickstream and customer input data combined with online information utility to enable more effective information serving. This requires further academic research and changes in practitioner online marketing operations.
\end{abstract}

Keywords: Online consumer behaviour modelling, complex products

\title{
Author biographies
}

Robert Grant lectures marketing subjects in the School of Management and Marketing at the University of Wollongong, specialising in Internet Marketing and Business to Business Marketing, and is an Associate Member of the Centre for Applied Systems Research. Primary research interest is consumer behaviour online with a focus on the possibility of systems to add consumer value in information exchanges, which is also the study of current $\mathrm{PhD}$ research. Related interests are inter-organisational cooperation in supply chain management. His career to date has been mainly in the tourism industry followed by consultancy services before moving to academia to pursue research interests. 
Rodney J. Clarke is Associate Professor of Management, School of Management and Marketing, University of Wollongong, Australia. His broad research areas include the contextual analysis of Information Systems (semiotics, linguistics and qualitative), multimedia, user interfaces, and distributed computing. He is Director of the Centre for Applied Systems Research, a group that promotes a 'social innovation' perspective in the analysis, design, implementation and evaluation of intra- and inter-organisational systems both organisational and technical, with a special interest in Business Processes, Services and Work Practices; Supply Chain, Simulation and Operations Management, and Organisational Multimedia and Hypermedia.

He has recently completed the postdoctoral award of Docent at Karlstad University, Sweden making him one of the most qualified Information Systems, Computing Science, or Information Technology academics in the Southern Hemisphere.

Elias Kyriazis is a Senior Lecturer, School of Management and Marketing, University of Wollongong, Australia. His broad research areas include the new product development, crossfunctional relationships and the role of marketing information in NPD. He is also a founding member of the Centre for Social Marketing and Non-Profit Research which undertakes programmes of active research into the applicability of commercial marketing principles and practices to the solution of societal and health related problems. In addition, the Centre has a strong research interest in non-profit marketing and the issue of corporate social responsibility. 


\section{INTRODUCTION}

If the internet is to become a fully fledged distribution channel, vendors need to deal with the reality of complex consumer behaviour and rethink the use of data derived from online information exchanges. Collaborative filtering practiced by organisations like Amazon.com offers the ability to dynamically serve product options based on product interests identified by browsing or purchase activity. But little attention has been given to the potential for using interactivity to improve online information services as a basis for consumer relationships. Website interactivity offers consumers control of information search activity for anticipated purchases while organisations achieve higher levels of engagement with searchers (Li et al., 2001; Klein, 2003). The benefits of such engagement with an information source are documented by Calder and Malthouse (2008) along with the complexity associated with delivering a subjectively evaluated experience. Key dimensions of an experience which achieves engagement are striking the right balance of affective or hedonic and functional content for an individual's experience.

The complexity identified by Calder and Malthouse (2008) is reflected in the wide range of searching research questions raised by Bolton and Saxena-Iyer's (2009) review. Bolton and Saxena-Iyer further show that a quality information service, which lowers consumer search costs, reduces price sensitivity and increases consumer pleasure and retention probability. For website information serving to be more responsive to consumer needs, interactivity must be used as the basis for consumer-vendor dialogue. However, the ability of a highly perceptive salesperson to discern a consumer's motives and needs during face-to-face service encounters, and who can act effectively to satisfy those needs, has yet to be replicated in online information exchanges.

To do this requires understanding individual consumer information search process needs as well as preferences for modality (online or offline), format (print, audio, video, interpersonal) and Page | 4 
information source type (public, personal or commercial) to satisfy those needs. As complex as this is, achieving a reliable information service offering delivery delivers three notable benefits. First an effective information service reduces customer information search time and effort adding customer value (e.g. Eighmy and McCord, 1998; Klein, 1998). Second the so-called "cognitive lock-in" effect (Johnson et al., 2003; Murray and Häubl, 2007) offers the prospect of repeat website use when vendors offer useful content in appropriate format. Third a reliable and responsive information service is likely to improve levels of consumer trust, a key factor in later purchase point selection (Eighmy and McCord, 1998; Peterson and Merino, 2003).

This paper reviews literature dealing with online consumer information search and identifies the limitations and contributions of current practices. Two research streams focus on different approaches to modelling and a third addresses consumer online information search utility. The first of the modelling approaches, clickstream analysis, uses live website click activity data to predict subsequent behaviour (Chatterjee et al., 2003; Moe, 2003; Johnson et al., 2004; Park and Fader, 2004) but lacks depth of insight and ability to deal with semantically complex behaviour. An alternative modelling approach, based on factors affecting breadth, depth and information sources selected, requires a complex array of hard to identify dynamic personal variables (Degeratu et al., 2003; Klein and Ford, 2003; Richard and Chandra, 2005). This complexity is perhaps the reason that Day (1998) suggested that: "The essence of Interactive Marketing is the use of information from the customer rather than about the customer." While Day's article was primarily concerned with organisation structure, perhaps one of the reasons for its relatively low citation rate is the lack of options for analysing data from the customer. This paper opens a discussion of possible ways to more effectively use information from the customer made available in online interactions. 
Finally research into online information utility reveals the complexity of information source preferences and a mix of functional (Eighmey and McCord, 1998; McGaughey and Mason, 1998; Ylikoski, 2005) and dysfunctional (Lee and Lee, 2004; Jones et al., 2005) online communication effects. To deal with this, marketers will have to understand the basis of a consumer's trade-offs between available options and the basis of such trade-offs. Such choices are likely to be highly related to individual contexts.

The paper is structured as follows. First, clickstream analysis literature is reviewed with specific attention to the conceptual basis of consumer information search behaviour and the nature of data collected using this approach. Second, literature identifying factors that affect the consumer information search process is reviewed to identify bases of online consumer behaviour. Third, literature regarding online utility for consumer information search is reviewed to identify the utility and effects of online information as compared to offline information. Fourth, an additional data source is proposed that, allied with existing methods, may bring the management of online customer interactions to a point where it can achieve responsive information offerings to customers based on their personal needs. In conclusion future academic research imperatives are discussed followed by the implications of such advances for practitioner marketing operations.

\section{INFORMATION SEARCH CLICKSTREAM MODELLING}

This section's focus is on clickstream modelling of information search and the insights offered into online consumer behaviour as well as the methodology of clickstream analysis. The critical contribution of clickstream modelling is its use of readily available data from server logs to model individual online consumer behaviour in real time. This modelling approach uses individual patterns and trends of recency, frequency and duration between mouse clicks within the website which can be accessed based on identification by login or locally stored cookie. Statistical models drawing on behavioural norms can then offer accurate predictions of an Page I 6 
individual's probability of returning to a given site or the propensity to click on a given link within the site. While such models are based on consumer heterogeneity and take no account of personal factors, they offer a number of important insights into online consumer behaviour. This section will firstly address behavioural insights derived from clickstream modelling and secondly the limitations of the method. Table 1 provides an overview of the literature reviewed in this section of the paper.

\begin{tabular}{|c|c|c|}
\hline Author(s) & Study focus & Key findings relevant to this section \\
\hline $\begin{array}{l}\text { Chatterjee, } \\
\text { Hoffman and } \\
\text { Novak (2003) }\end{array}$ & $\begin{array}{l}\text { Clickstream analysis of response to } \\
\text { online stimuli }\end{array}$ & $\begin{array}{l}\text { Needs for dynamic models for information serving } \\
\text { based on intrasession as well as intersession effects. }\end{array}$ \\
\hline $\begin{array}{l}\text { Grant, Clarke and } \\
\text { Kyriazis (2007) }\end{array}$ & $\begin{array}{l}\text { Value based benefits and } \\
\text { constraints of online information }\end{array}$ & $\begin{array}{l}\text { Probability of need for multiple information sources in } \\
\text { complex consumer purchase behaviour. }\end{array}$ \\
\hline $\begin{array}{l}\text { Johnson, Bellman } \\
\text { and Lohse (2003) }\end{array}$ & $\begin{array}{l}\text { Cognitive lock-in effects of } \\
\text { repeated application use. }\end{array}$ & $\begin{array}{l}\text { The effects of experience based learning in developing } \\
\text { consumer loyalty to a website. Shorter visit times and } \\
\text { easier learning as facilitation for buying. }\end{array}$ \\
\hline $\begin{array}{l}\text { Johnson, Moe, } \\
\text { Fader, Bellman } \\
\text { and Lohse (2004) }\end{array}$ & $\begin{array}{l}\text { Depth, dynamics and activity of } \\
\text { search. Effects of lower search } \\
\text { costs on search effort and inter site } \\
\text { competition }\end{array}$ & $\begin{array}{l}\text { Lower than expected search for commodity type } \\
\text { products. Higher search for higher involvement air } \\
\text { tickets with seasonal effects. }\end{array}$ \\
\hline $\begin{array}{l}\text { McGaughey and } \\
\text { Mason (1998) }\end{array}$ & $\begin{array}{l}\text { Internet influence on buyer } \\
\text { behaviour through buying process }\end{array}$ & $\begin{array}{l}\text { Need to understand consumer heuristic strategy for } \\
\text { information presentation to aid decisions and } \\
\text { interaction options for building dialogue. }\end{array}$ \\
\hline Moe (2003) & $\begin{array}{l}\text { Clickstream typology of consumer } \\
\text { activity within a particular visit }\end{array}$ & $\begin{array}{l}\text { Taxonomy of website visitor motivation as goal } \\
\text { directed, search/deliberation, hedonic and knowledge } \\
\text { building visitors. Shows ability to differentiate } \\
\text { behaviour by information search activity online }\end{array}$ \\
\hline $\begin{array}{l}\text { Murray and Häubl } \\
\text { (2007) }\end{array}$ & $\begin{array}{l}\text { Consumer preference for websites } \\
\text { based on prior usage experience }\end{array}$ & $\begin{array}{l}\text { The effects of interface specific experience on future } \\
\text { consumer choices based on skill based habits of use } \\
\text { rather than habitual choice. Recognizes value of lower } \\
\text { cognitive costs associated with learning effects. }\end{array}$ \\
\hline $\begin{array}{l}\text { Park and Fader } \\
\text { (2004) }\end{array}$ & $\begin{array}{l}\text { Effects of modelling data from two } \\
\text { sites for behaviour prediction }\end{array}$ & $\begin{array}{l}\text { Including clickstream data from a second site results in } \\
\text { better predictive modelling of consumer behaviour for } \\
\text { standardized "search" type products. }\end{array}$ \\
\hline $\begin{array}{l}\text { Peterson and } \\
\text { Merino (2003) }\end{array}$ & $\begin{array}{l}\text { Limitations of internet utility. } \\
\text { Need for research focus on } \\
\text { moderators and interactions of } \\
\text { search behaviours rather than main } \\
\text { effects based on multiple effects } \\
\text { and applications. }\end{array}$ & $\begin{array}{l}\text { Key moderators proposed as consumer characteristics, } \\
\text { type of information sought, product characteristics, } \\
\text { search motivation and sources used. Also identifies } \\
\text { consumer preferences for interpersonal interaction. }\end{array}$ \\
\hline
\end{tabular}

Table 1: Consumer information search research based on clickstream modelling

\subsection{Clickstream behavioural insights}

Chatterjee et al's (2003) research established the importance of using data from across and within the consumer's browsing sessions on a website to develop insights into online behaviour. This requires using a database to store the prior records of the identified individual's behaviour and 
drawing on those records while modelling current behaviour in real time. Their research also reinforces the value of effective website information services to achieve "cognitive lock-in" (Johnson et al., 2003; Murray and Häubl, 2007) showing that unused links are increasingly less likely to be used on subsequent visits. This suggests that failure to deliver the right information up front compromises further clicks, engagement and later activity resulting in consumer perceptions of error and dissatisfaction negating "cognitive lock-in." Links that do address consumer needs to the degree of attracting clicks are more likely to raise perceptions of website functionality with attendant learning and loyalty effects associated with "cognitive lock-in." The importance of "cognitive lock-in" is supported by Johnson et al's (2004) evidence of growing search behaviour over time for even highly standardized "search" type products. This trend to more extensive search behaviour with growing consumer internet use suggests that "cognitive lock-in" is a key to maximizing relative share of consumer search time on a website.

Clickstream analysis also has the potential to move beyond predicting subsequent click behaviour by adding content analysis of pages accessed within a website (Moe, 2003). By classifying website pages as administrative, product or informational, Moe was able to differentiate between purchase intention and information seeking based on long or short term consumer objectives. This ability to discern consumer search motivation by adding page types accessed to consumer click patterns is an important extension of clickstream modelling as it can be linked to information and navigation preferences. Surprisingly this line of research has not been pursued further, for example with content specific page content rather than the generic page classification used by Moe.

\subsection{Limitations of clickstream modelling}

A major limitation in modelling data from a single website is shown in lower systemic error and higher predictive modelling accuracy achieved by using data from a competitive site (Park and Page 18 
Fader, 2004). Use of panel data gave Park and Fader access to data from a competitive site so that the model addressed the trend to wider search activity (Johnson et al., 2004) for "search" products such as books and CD's. Unfortunately the application of panel data is limited to research for website business planning and real time use for delivery of dynamic website content is not possible. An alternative method is therefore required for identifying consumer activity beyond the website for better modelling practice. Where complex consumer behaviour results in use of multiple information sources to deal with complex or novel products (Grant et al., 2007), absence of competitor data will likely compromise model development to an even greater degree. Therefore, modelling behaviour associated with first time purchase of new technology, such as plasma or LCD TV's, or semantically complex products such as unfamiliar distant holiday destinations will require alternative data sources for effective model development.

A further limitation of clickstream modelling is inability to monitor reactions to information on a web page; for example does a click to an alternative page or away from the site suggest satisfaction from an achieved objective or frustration with information that does not satisfy their needs? This requires approaching website information exchange from the perspective of communication theory which accounts for the effects of information beyond its simple availability. Extending Moe's (2003) research to combine page content specifications with patterns of mouse clicks offers the potential to categorize path typologies for website search behaviour. Given identification of activity motivation from content analysis, behaviour typologies may manifest as personal heuristics, dependent on personal and product factors that will be discussed in the following section (McGaughey and Mason, 1998; Moe, 2003; Peterson and Merino, 2003). Divergence from an identified pattern may indicate a change in needs or circumstances and alternative information offered to remedy the situation. But this still fails to address the effects of consumer information search elsewhere online or even offline in the case of multimodal behaviour (Grant et al., 2007). 


\subsection{Clickstream modelling summary}

Beyond offering the basis of using online consumer behaviour on a website as data in real time, clickstream modelling offers important behavioural insights. Notably the importance of offering appropriate information up-front to achieve cognitive lock-in and the need to use data both from within and across an individual's browsing sessions. There is also the potential to add data beyond click analysis as Moe (2003) did with page type classifications to develop insights into consumer motivation. However, the potential to improve modelling of search for simple products by data from beyond the vendor's website indicates that even greater problems are likely to arise when modelling complex behaviour. This suggests a need to build on the rigor of clickstream modelling by incorporating off-site consumer information effects as well as the effects of information offered to consumers. By introducing other factors in online consumer information search behaviour such as activity motivation and personal and product factors, behaviour based heuristics of consumer choice rules may be identified. Such an approach also offers the possibility of improving model development by removing the heterogeneity condition that applies in clickstream models by identifying personal factors. The following section of this paper therefore reviews literature on factors affecting online information search activity.

\section{INFORMATION SEARCH FACTOR MODELLING}

An alternative approach to behavioural modelling is defining factors which affect behaviour and then determining the relative impact of each factor using multiple regression in structural equation modelling. As pointed out in the previous section, identifying such factors may improve clickstream modelling by removing the attendant heterogeneity condition. This raises the possibility of identifying heuristic typologies for behaviour patterns associated with needs for quantum of information and preferences for source types. By identifying factors associated with specific behaviours, such as personal and product factors, underlying consumer needs which Page I 10 
dictate information source type and format requirements may be determined. The literature identifies two main personal factor groups, stable traits and transitory states, as well as product and motivation factors that affect online information search behaviour. This section will be divided into these areas because of the different challenges posed by modelling each of these groups of factors. Table 2 provides an overview of the literature reviewed in this section of the paper.

\begin{tabular}{|c|c|c|}
\hline Author(s) & Study focus & Key findings relevant to this section \\
\hline $\begin{array}{l}\text { Bettman et al } \\
\text { (1991) }\end{array}$ & $\begin{array}{l}\text { Properties of consumer decision } \\
\text { making task and environment }\end{array}$ & $\begin{array}{l}\text { Consumer heuristic strategies used to deal with } \\
\text { limited processing ability and characteristics of } \\
\text { strategies identified. Effects of task, social and } \\
\text { personal contexts on strategies used. }\end{array}$ \\
\hline $\begin{array}{l}\text { Cacciopo et al } \\
\text { (1996) }\end{array}$ & $\begin{array}{l}\text { Conceptual base and factors relating } \\
\text { to individual need for cognition }\end{array}$ & $\begin{array}{l}\text { Consistency of literature in identifying a major single } \\
\text { factor relating to individual likelihood to engage in } \\
\text { and enjoy effortful cognitive activity. Based on the } \\
\text { need of people to make sense of or derive meaning } \\
\text { relating to phenomena of interest. }\end{array}$ \\
\hline $\begin{array}{l}\text { Conchar et al } \\
(2004)\end{array}$ & $\begin{array}{l}\text { Consumer management of perceived } \\
\text { risk as a process }\end{array}$ & $\begin{array}{l}\text { Role of personal, product and situational factors in } \\
\text { perceived consumer risk and behaviour resulting. }\end{array}$ \\
\hline $\begin{array}{l}\text { Degeratu, } \\
\text { Rangaswamy and } \\
\mathrm{Wu}(2000)\end{array}$ & $\begin{array}{l}\text { Search attribute effects on consumer } \\
\text { behaviour online and offline }\end{array}$ & $\begin{array}{l}\text { Brand names add value online for products lacking in } \\
\text { attribute information. Objective information has a } \\
\text { positive effect on online product selections. }\end{array}$ \\
\hline Hill (2001) & $\begin{array}{l}\text { Dealing with emotional responses } \\
\text { online }\end{array}$ & $\begin{array}{l}\text { Need to understand sensory, emotional and rational } \\
\text { responses to stimuli in terms of reaction to and appeal } \\
\text { of offering. }\end{array}$ \\
\hline Klein (2003) & $\begin{array}{l}\text { Effects of user control and media } \\
\text { richness in virtual experience }\end{array}$ & $\begin{array}{l}\text { Telepresence effects on consumer attitudes and } \\
\text { beliefs about products and influence on cognitive } \\
\text { responses. Substitute for direct product experience. }\end{array}$ \\
\hline $\begin{array}{l}\text { Klein and Ford } \\
\text { (2003) }\end{array}$ & $\begin{array}{l}\text { Use of the internet in product } \\
\text { information search and substitution } \\
\text { of offline media }\end{array}$ & $\begin{array}{l}8 \text { Cell matrix conceptualization of source types, with } \\
\text { internet substitution resulting in greater search. Need } \\
\text { to understand breadth and depth of search as much as } \\
\text { time spent on each source. }\end{array}$ \\
\hline $\begin{array}{l}\text { Lohse, Bellman } \\
\text { and Johnson } \\
\text { (2000) }\end{array}$ & $\begin{array}{l}\text { Predicting market adoption of online } \\
\text { purchasing }\end{array}$ & $\begin{array}{l}\text { Time scarcity and "wired" lifestyle superiority to } \\
\text { demographics in predicting online purchasing. }\end{array}$ \\
\hline Moon (2004) & $\begin{array}{l}\text { Propositions for researching internet } \\
\text { adoption for product search and } \\
\text { purchase }\end{array}$ & $\begin{array}{l}\text { Contingent decision making based on personal and } \\
\text { product factors context of purchase. }\end{array}$ \\
\hline $\begin{array}{l}\text { Peterson and } \\
\text { Merino (2003) }\end{array}$ & $\begin{array}{l}\text { Limitations of internet utility. Need } \\
\text { for research focus on moderators and } \\
\text { interactions of search behaviours } \\
\text { rather than main effects based on } \\
\text { multiple effects and applications. }\end{array}$ & $\begin{array}{l}\text { Key moderators proposed as consumer } \\
\text { characteristics, type of information sought, product } \\
\text { characteristics, search motivation and sources used. }\end{array}$ \\
\hline $\begin{array}{l}\text { Ratchford, Lee } \\
\text { and Talukdar } \\
\text { (2003) }\end{array}$ & $\begin{array}{l}\text { Changes in high involvement search } \\
\text { behaviour since introduction of the } \\
\text { internet. Internet sources as } \\
\text { substitutes and search effort effects }\end{array}$ & $\begin{array}{l}\text { Mixed modes of search used with different sources } \\
\text { for search and experience dimensions. Perceived cost } \\
\text { of time dependent on search motivation with many } \\
\text { doing surprisingly little search }\end{array}$ \\
\hline $\begin{array}{l}\text { Richard and } \\
\text { Chandra (2005) }\end{array}$ & $\begin{array}{l}\text { Website navigation based on "flow" } \\
\text { model of responses to site } \\
\text { characteristics. }\end{array}$ & $\begin{array}{l}\text { Flow, personal and situational factors and web } \\
\text { navigation effects on consumer outcomes. } \\
\text { Importance of skill, challenge, need for cognition and } \\
\text { optimum stimulation level. }\end{array}$ \\
\hline $\begin{array}{l}\text { Spink and Gunnar } \\
\text { (2001) }\end{array}$ & Review of business internet searches & $\begin{array}{l}\text { Business searching more focused, typically on other } \\
\text { organisations and most related to sourcing inputs. } \\
\text { Need for inter-site comparability and better }\end{array}$ \\
\hline
\end{tabular}




\begin{tabular}{|l|l|l|}
\hline $\begin{array}{l}\text { Steenkamp and } \\
\text { Baumgartner } \\
(1992)\end{array}$ & $\begin{array}{l}\text { Role of optimum stimulation levels } \\
\text { in exploratory consumer behaviour }\end{array}$ & $\begin{array}{l}\text { Optimum stimulation levels systematically related to } \\
\text { consumer curiosity, variety seeking and risk taking. }\end{array}$ \\
\hline $\begin{array}{l}\text { Yoon and Kim } \\
(2001)\end{array}$ & $\begin{array}{l}\text { Media and product related } \\
\text { characteristics as factors in } \\
\text { consumer information media choice }\end{array}$ & $\begin{array}{l}\text { Internet has greater utility for high involvement and } \\
\text { rational approaches. }\end{array}$ \\
\hline
\end{tabular}

Table 2: Consumer information search research based on factor modelling

\subsection{Stable personal factors}

Richard and Chandra (2005) applied structural equation modelling to online information search and identified the importance of both an individual's dynamic states and stable traits in their information search activity. The personal trait factors they identified, likely to remain stable over time, included personality factors of "need for cognition" and "optimum stimulation level." Both need for cognition (Caccioppo et al., 1996) and optimum stimulation levels (Steenkamp and Baumgartner, 1992) affect information format preferences and overall quantity of search. However classifying individuals on these variables requires extensive survey instruments that may irritate goal directed consumers and therefore be problematic for a vendor.

Another longer run factor influencing online search behaviour is that of personal lifestyles, in particular a time poor/cash rich profile (Degeratu et al., 2000) associated with a preference for online information. This echoed the finding of Lohse et al. (2000) who termed "a wired lifestyle" as the most significant predictor of online search and purchase. Again however, gaining insights into an individual's multi-faceted lifestyle requires an extensive survey instrument likely to annoy consumers. Similar difficulties are associated with other personal factors which are significant in consumer online search behaviour such as education and income levels (Klein and Ford, 2003).

Assuming the problems associated with collecting such data can be resolved there are clear benefits from using a database to record such insights which may be drawn on in modelling a consumer's activity on a website in real time. However the complexity of modelling the likely 
interactions between the effects of education and income, lifestyle and personality factors is likely to remain a significant challenge for marketers.

\subsection{Dynamic personal factors}

Richard and Chandra (2005) also identified effects of cognitive and search skill levels, which evolve through the search process, resulting in consumer need changes as they progress through the process. Such factors not only present a challenge for data collection like long term traits with a further challenge of appraising their real time development through the process. Other dynamic factors such as levels of product knowledge and use of internet applications (Klein and Ford, 2003) are also likely to evolve through the search process. The consumer's information needs are likely to change as product knowledge and search skills grow over the time of their search, so such changes require real time assessment. This compounds the problems identified for survey based insights for consumer traits as data collection is not only problematic, but also static, representing the situation at a point in time. Such insights will be redundant as needs change and develop through the process so an alternative is needed for monitoring such factors in real time.

A further dynamic factor that may result in changes to the consumer's mood or attitude is their reaction to website page information. This point was raised in the section on clickstream modelling and unfortunately there is no apparent solution in the literature relating to factor based modelling. Determining whether the consumer is satisfied or dissatisfied following exposure to a website page is important as a basis for determining the needs which follow such a change in state. A remedial response for dissatisfaction may require alternative product offerings while a satisfied response may require access to greater depth of information to facilitate their evaluation process. Polling for levels of satisfaction may however irritate consumers and, unless the bases of satisfaction or dissatisfaction are determined, have limited value for a vendor's system of dynamic content delivery. The key issue is to move beyond a focus on what information is being 
offered to a consumer on a website and to develop an understanding of the effects of such information.

One method of monitoring consumer responses in real time is using biofeedback to identify sensory, rational and emotional responses to online stimuli based on facial coding and monitoring (Hill, 2001). But such methods are used in laboratory settings and impractical for live website exchanges. Hill's research does however identify the importance of rational and emotional reactions to stimuli which influence further information search needs. Understanding such rational and emotional reactions may offer further insights to needs relating to the consumer's motivation for purchase. This again offers useful clues for information offerings since a purchaser with primarily rational motives is likely to prefer objective information that reflects performance or other definitive attributes. An emotionally driven purchaser on the other hand may be more interested in subjective information relating to the image or use of the product of interest.

\section{3 "Other" factors in information search}

Richard and Chandra's (2005) focus on factors relating to "flow" failed to identify a range of other factors that affect information search. Degeratu et al. (2000) for example identified the higher importance of brand credibility as a surrogate for sensory information that cannot be conveyed without touch, taste or smell. In such situations, personal inspection offers greater utility than online representations. For online purchasers however an understanding of their attitude to the brand relative to competitors may offer useful insights into a source of individual information search process needs.

The other key factor that influences consumer online information search is the nature of the product for which the consumer is searching. The higher the level of involvement the consumer has with the product the more extensive the search is likely to be (Yoon and Kim, 2001) as the Page | 14 
consumer strives to reduce risk or gains hedonic gratification from engagement with an important topic. The nature of the product's attributes will also influence information source preferences with subjective information preferred from offline information sources and objective information from online information sources (Klein, 2003; Peterson and Merino, 2003; Ratchford et al., 2003). Many products however have both subjective and objective dimensions and the consumer's purchase motivation has to be understood to appreciate which types of information sources are required. For example the motoring purist may require factual performance and specification information when considering the purchase of a high performance motor car. Another person considering the same car based on associated image effects may prefer subjective or opinion based information sources. Similarly, degree of involvement with a product can vary between people with a wealthy person regarding the purchase of a high performance motor car as a new "toy" compared to self-actualisation for a motoring enthusiast. This basic illustration shows the potential for interactions between the factors, requiring individual models based on personal characteristics, motivation for purchase and involvement with the product.

\subsection{Summary of consumer search factor modelling}

In summary, real time behaviour modelling requires data relating to stable personal factors, dynamic learning effects through the process and consumer reactions to information to extend current modelling practices. With such a complex set of both stable and dynamic personal factors, which will also vary between products for an individual, the construction of models to explain behaviour based on such variables is problematic. These factors are compounded by product factors such as purchase motivation and degree of the consumer's involvement with the product. Using such factors for modelling purposes using conventional structural equation modelling is compromised on two fronts. Firstly gathering data, particularly for dynamic effects and changing needs, is likely to be problematic. Secondly the number of factors, and the probability of 
interaction effects between them, suggests that model complexity will be beyond favoured parsimonious solutions.

The alternative may lie in a fundamental shift in thinking from the impracticalities of data about the customer to data from the customer as advocated by Day (1998). The difficulty in determining what data from the customer is likely to give the required insights is perhaps why Day's paper addressed the issue of organisation structure. Clickstream data fits the description of data from the customer but is unable to model complexity in its current form as described in this section. Introducing new variables will therefore be required with a different method of analysis starting with more detailed descriptors of the page contents a consumer is accessing. Moe (2003) showed that with basic characterisations of web pages consumer motivation for activity may be defined. More detailed classifications, perhaps at the level of individual page name space, may offer the possibility of identifying heuristic patterns of behaviour that may be associated with individual needs.

Research to investigate the bases of heuristic behavioural typologies discovered through clickstream data analysis as outlined in the previous section, may then enable factor attribution to behavioural patterns. Heuristic typologies are associated with distinctive patterns of behaviour (Bettman et al., 1991) and may be explained by personal and product factors which play a role in perceived risk management (Conchar et al., 2004). The linkage between such personal and product factors and contingent decision making in online information search behaviour (Moon, 2004) suggests that this is a key opportunity for identifying information search needs. Because of the impracticality of conventional marketing research methods alternative methods will be required to address complex information search and relieve the heterogeneity of clickstream modelling. Before proposing methods to do this however, this paper reviews effects of online 
consumer information utility on choices of information search to canvass methods of determining which information sources and formats to serve.

\section{INFORMATION SEARCH UTILITY}

A key aspect of online information utility for consumers is an appreciation of limitations that result in trade-offs for consumers choosing between various information source types and formats. While a website can offer links to a massive array of alternative information, the effects of cognitive costs (Jensen et al., 2003; Ratchford et al., 2003) and potential for information overload (Lee and Lee, 2004) suggest that offering appropriate information will add customer value. The key question arising here is the roles of (a) different types of information source (public, private or commercial), (b) different formats of information (print, audio, video or interpersonal) and (c) modality of information (online or offline). Since complementarities are likely between sources, formats and modes of information source (Grant et al., 2007) their roles need to be understood to enable responsive information service.

There are however a range of attributes and effects associated with offline information sources and formats that consumers may trade-off in preference for online information sources. This paper now reviews literature dealing with the utility of online information and identifies a number of unresolved trade-offs that are likely to apply in consumer information search. This section addresses content utility, dealing with depth and breadth of information and mode utility dealing with preferences for online or offline information. Since utility is not a purely mechanistic function of serving however a third sub-section deals with personal factors to touch on human needs affecting information utility. Table 3 provides an overview of the literature reviewed in this section of the paper.

\begin{tabular}{|l|l|l|}
\hline Author(s) & Study focus & Key findings relevant to this section \\
\hline $\begin{array}{l}\text { Bettman et al } \\
(1991)\end{array}$ & $\begin{array}{l}\text { Properties of consumer decision making } \\
\text { task and environment }\end{array}$ & $\begin{array}{l}\text { Consumer heuristic strategies used to deal with } \\
\text { limited processing ability and characteristics of } \\
\text { strategies identified. Effects of task, social and }\end{array}$ \\
\hline
\end{tabular}




\begin{tabular}{|c|c|c|}
\hline & & personal contexts on strategies used. \\
\hline $\begin{array}{l}\text { Brown and } \\
\text { Duguid (2000) }\end{array}$ & $\begin{array}{l}\text { Limitations of information applications } \\
\text { in business strategy. Reversal of } \\
\text { insufficient information for decisions } \\
\text { problem }\end{array}$ & $\begin{array}{l}\text { Data availability does not supplant need for social } \\
\text { institutions and organisations. Original applications } \\
\text { may thrive on information rather than being } \\
\text { replaced by them. }\end{array}$ \\
\hline $\begin{array}{l}\text { Brown and Sellen } \\
(2001)\end{array}$ & $\begin{array}{l}\text { User management of repeat site visits, } \\
\text { cross-site information comparison and } \\
\text { security and privacy }\end{array}$ & $\begin{array}{l}\text { Design implications for consumer interface. Need } \\
\text { for inter-site information comparability and security } \\
\text { of online transactions. }\end{array}$ \\
\hline $\begin{array}{l}\text { Eighmy and } \\
\text { McCord (1998) }\end{array}$ & $\begin{array}{l}\text { Websites use and consumer } \\
\text { gratification, similarities to other media } \\
\text { and need for continued relationship and } \\
\text { personal involvement }\end{array}$ & $\begin{array}{l}\text { Importance of website information, entertainment } \\
\text { and organisation to add consumer utility. }\end{array}$ \\
\hline $\begin{array}{l}\text { Grant, Clarke and } \\
\text { Kyriazis (2007) }\end{array}$ & $\begin{array}{l}\text { Value based benefits and constraints of } \\
\text { online information }\end{array}$ & $\begin{array}{l}\text { Likely complementarities of information source } \\
\text { types and formats for complex consumer purchase } \\
\text { behaviour. Potential for multimodal information } \\
\text { search. }\end{array}$ \\
\hline $\begin{array}{l}\text { Jensen, Kees, } \\
\text { Burton and } \\
\text { Turnipseed (2003) }\end{array}$ & $\begin{array}{l}\text { Effects on price perceptions and search } \\
\text { intentions of reference prices advertised } \\
\text { online }\end{array}$ & $\begin{array}{l}\text { Higher search intentions online than offline. Shows } \\
\text { need for consumers to supplement online search } \\
\text { with offline search. }\end{array}$ \\
\hline $\begin{array}{l}\text { Jones, Pentecost } \\
\text { and Requena } \\
(2005)\end{array}$ & Information effects online and offline & $\begin{array}{l}\text { Recall and recognition effects of online and offline } \\
\text { communications for persuasion and information. } \\
\text { Brand names and persuasive information recall } \\
\text { worse online. }\end{array}$ \\
\hline Klein (1998) & $\begin{array}{l}\text { Internet search behaviour differences } \\
\text { between search and experience products } \\
\text { based on economics and media } \\
\text { attributes }\end{array}$ & $\begin{array}{l}\text { Importance of vicarious experience and/or trial for } \\
\text { managing higher perceived risk online. Potential to } \\
\text { add consumer value with information. }\end{array}$ \\
\hline Klein (2003) & $\begin{array}{l}\text { Effects of user control and media } \\
\text { richness in virtual experience }\end{array}$ & $\begin{array}{l}\text { Telepresence effects on consumer attitudes and } \\
\text { beliefs about products and influence on cognitive } \\
\text { responses. Substitute for direct product experience. }\end{array}$ \\
\hline $\begin{array}{l}\text { Lee and Lee } \\
(2004)\end{array}$ & $\begin{array}{l}\text { Effects of changing attribute and option } \\
\text { numbers and attribute level effects } \\
\text { across options on consumer choices }\end{array}$ & $\begin{array}{l}\text { Numbers of attributes and attribute level } \\
\text { distributions are better predictors of information } \\
\text { overload online than number of options or attributes } \\
\text { alone. }\end{array}$ \\
\hline $\begin{array}{l}\text { Li, Daugherty and } \\
\text { Biocca (2001) }\end{array}$ & $\begin{array}{l}\text { Effects of 3-D or virtual experience } \\
\text { interactions }\end{array}$ & $\begin{array}{l}\text { Virtual experience as substitute for sensory } \\
\text { stimulation in buying. Effects of presence, } \\
\text { involvement with product and affordance based } \\
\text { enjoyment on intention to purchase. }\end{array}$ \\
\hline $\begin{array}{l}\text { McGaughey and } \\
\text { Mason (1998) }\end{array}$ & $\begin{array}{l}\text { Internet influence on buyer behaviour } \\
\text { through buying process }\end{array}$ & $\begin{array}{l}\text { Online search facilitated by offering links to other } \\
\text { sites, understanding of preferred heuristic for } \\
\text { information offering to aid decisions and interaction } \\
\text { options for building dialogue. }\end{array}$ \\
\hline $\begin{array}{l}\text { Peterson and } \\
\text { Merino (2003) }\end{array}$ & $\begin{array}{l}\text { Limitations of internet utility. Need for } \\
\text { research focus on moderators and } \\
\text { interactions of search behaviours. }\end{array}$ & $\begin{array}{l}\text { Key moderators proposed as consumer } \\
\text { characteristics, type of information sought, product } \\
\text { characteristics, search motivation and sources used. } \\
\text { Key moderator is consumer product knowledge } \\
\text { level. }\end{array}$ \\
\hline $\begin{array}{l}\text { Ratchford, Lee } \\
\text { and Talukdar } \\
(2003)\end{array}$ & $\begin{array}{l}\text { Changes in high involvement search } \\
\text { behaviour since introduction of the } \\
\text { internet. Internet sources as substitutes } \\
\text { and search effort effects }\end{array}$ & $\begin{array}{l}\text { Mixed modes of search used with different sources } \\
\text { for search and experience dimensions. Perceived } \\
\text { cost of time dependent on search motivation with } \\
\text { many doing surprisingly little search }\end{array}$ \\
\hline Redmond 2002 & $\begin{array}{l}\text { Potential impact of shopping agents in } \\
\text { e-commerce markets }\end{array}$ & $\begin{array}{l}\text { Inflexibility of search technology leading to poor } \\
\text { search results, information processing and erosion } \\
\text { of differentiation benefits and customer loyalty. }\end{array}$ \\
\hline $\begin{array}{l}\text { Yoon and Kim } \\
(2001)\end{array}$ & $\begin{array}{l}\text { Media and product related } \\
\text { characteristics as factors in consumer } \\
\text { information media choice }\end{array}$ & $\begin{array}{l}\text { Internet has greater utility for high involvement and } \\
\text { rational approaches. Curious characterization of } \\
\text { cars and luxury watches as rational purchases. }\end{array}$ \\
\hline
\end{tabular}

Table 3: Consumer information search research based on information search utility 


\subsection{Content utility}

The key content utility of online information is the depth and breadth of information available (Eighmy and McCord, 1998) with ease of access through search engines and hyperlink navigation between and within websites (McGaughey and Mason, 1998). However differing attribute treatment between websites (Brown and Sellen, 2001) heightens the potential for information overload (Lee and Lee, 2004) with adverse consequences for consumers. Online information sources may even compound the problem by offering "help" in the form of even more information to deal with information overload (Brown and Duguid, $2000 \mathrm{p} \mathrm{14}$ ). Another frustration for online consumer information search is the lack of personal engagement derived from website interactions (Klein, 1998; Brown and Duguid, 2000 pp 18-19; Brown and Sellen, 2001; Peterson and Merino, 2003). This lack of personal interaction appears to be an impediment to development of cognitive lock-in as it is a barrier to repeat website use based on trust and may contribute to multimodal consumer information search behaviour (Grant et al., 2007).

The volume of online information also compromises the utility of widely used search engines because of the diversity of consumer search terms which often return sub-optimal results. Redmond (2002) demonstrated such frustration with search engine use based on the law of adverse selection notwithstanding the use of "fuzzy logic." However the success of Google's search engine suggests widespread consumer use, and so the trade off between effective use and consumer frustration needs to be better understood. Similarly, understanding consumer trade-offs between information availability online and negatives such as lack of personal engagement and overload potential may be a key factor in defining personal heuristics (Bettman et al., 1991). Where access to both online and offline information sources results in multimodal search in preference to making trade-offs, the roles of online and offline information sources of various formats needs to be identified. This will require an understanding of mode and format attributes 
involved in trade-offs or role selection to develop a basis for the heuristic classifications which can then be applied to the behaviour patterns identified by content based clickstream analysis.

\subsection{Mode utility}

Another limitation of online information is consumer preference for some information types delivered offline rather than online. For example, Ratchford et al. (2003) found consumer preference for subjective information from independent sources offline, while factual information was preferred online often from commercial sources. A possible reason for this is the different cognitive effects of online information found in lower recall compared to offline hardcopy print information (Jones et al., 2005). This effect was found to be independent of comfort with using technology as well as respondent knowledge prior to the study suggesting that it us purely a difference between modes of information access. This may even compound information overload effects as consumers struggle to recall information for evaluation, further reducing utility.

There are however strong positive cognitive effects from interactive online information particularly when combined with rich media such as video to achieve "telepresence." Also, consumers given the ability to manipulate views of a product online had greater psychological engagement than those using offline "impersonal" media ( $\mathrm{Li}$ et al., 2001) seemingly reflecting appreciation of interactivity. Klein (2003) extended this work with experiments which showed the potential for "telepresence" by adding rich media to interactivity in the form of navigation control. "Telepresence" was found to result in higher levels of cognitive engagement from the combination of consumer empowerment and audio visual information delivery that is possible online. Interestingly, rich media using video representation of a personal guide for participants seems to support the benefit of a "personal" dimension in online communication. Significantly, both Li et al's (2001) and Klein's (2003) research was done in the context of "experience" type 
products rather than the "search" type products of books and CD's commonly researched for clickstream analysis.

The positives and negatives associated with online information do not necessarily lead to discrete choice of mode for consumers as Jensen et al. (2003) showed in their study of modal search intention related to price perceptions and reference pricing online and offline. Their findings clearly pointed to the probability of multimodal information search behaviour with consumers supplementing online search with offline search. This further reinforces the need for responsive modelling of online behaviour to appraise the consumer's change in state at the start of a new browsing session to account for new knowledge and possibly attitude changes between sessions.

\subsection{Personal factors in information utility}

As well as variances in information sources, human needs (like frustration with impersonal online information mentioned earlier) associated with information search activity must be dealt with. This frustration with the impersonality of websites is associated with lack of consumer trust and is a substantial constraint to the value of online information sources (Eighmy and McCord, 1998; Peterson and Merino, 2003). Consumer need for, or willingness to, trust is a likely effect of personal psychological factors identified for factor modelling earlier in this paper. Brown and Duguid (2000) offer a further persuasive argument of the need to understand how social structures and society shape the way information is used suggesting a need to understand the consumer's societal context. Other personal factors which affect information utility are the level of rationality or emotion (Yoon and Kim, 2001) attached to the individual's motivation for purchase. Similarly other personal factors such as need for cognition, optimum stimulation level and education are also likely to have an effect on information source utility as pointed out in earlier sections of this paper. 


\subsection{Summary of online information source utility}

The key requirement for modelling online consumer information search from an information source utility aspect is to identify the trade-offs between the options available to them. This will require research into the needs associated with preferences for information source types, formats and mode and relating them to heuristic behaviour typologies identified from clickstream data. In addition the relative roles and complementarities of different information sources also must be understood to appreciate the sequencing of different information preferences in an information search process.

Before summarising, one further source of information from the customer on the internet (Day, 1998) requires further attention. While the bulk of consumer activity online may be in the form of clicks on a website, reflecting the value of this method of navigation shown by Ylikoski (2005), there are also opportunities for linguistic expression. Consumers may select words as search terms, for queries on website forms, as e-mails and participating in online forums or contributing to bulletin boards. The use of language in expression can of course be captured for analysis and is an important and highly valuable source of insights to customer needs as discussed in the following section.

\section{CUSTOMER EXPRESSION AS DATA}

Positive effects of higher cognitive engagement, envisaged spend and propensities for purchase are related to consumer online forum use relative to vendor online information for "experience" type products (Bickart and Schindler, 2001). Consumer use of such forums is clearly of value to vendors in generating customer engagement and user information content on a website and participation in such information exchanges should be encouraged. This section of the paper proposes consumer text inputs in such forums as a key data source for understanding three key 
factors in online information search behaviour. Table 4 provides an overview of the literature

reviewed in this section of the paper.

\begin{tabular}{|c|c|c|}
\hline Author(s) & Study focus & Key findings relevant to this section \\
\hline $\begin{array}{l}\text { Bagozzi and } \\
\text { Dholakia } 2002\end{array}$ & $\begin{array}{l}\text { Determinants of social action in } \\
\text { virtual communities }\end{array}$ & $\begin{array}{l}\text { Virtual community influences of compliance, } \\
\text { internalization and social identity. Participation based on } \\
\text { both individual gratification and community influences. }\end{array}$ \\
\hline $\begin{array}{l}\text { Bickart and } \\
\text { Schindler } 2001\end{array}$ & $\begin{array}{l}\text { Relative values of forums and } \\
\text { commercial sources as consumer } \\
\text { information. }\end{array}$ & $\begin{array}{l}\text { Online forum information results in higher level interest, } \\
\text { thought, knowledge, expected spending and purchase } \\
\text { likelihood. }\end{array}$ \\
\hline $\begin{array}{l}\text { Brown and } \\
\text { Duguid (2000) }\end{array}$ & $\begin{array}{l}\text { Limitations of information } \\
\text { applications in business strategy. } \\
\text { Reversal of insufficient } \\
\text { information for decisions problem }\end{array}$ & $\begin{array}{l}\text { Data availability does not supplant need for social } \\
\text { institutions and organisations. Original applications may } \\
\text { thrive on information rather than being replaced by them. }\end{array}$ \\
\hline $\begin{array}{l}\text { Brown and Sellen } \\
(2001)\end{array}$ & $\begin{array}{l}\text { User management of repeat site } \\
\text { visits, cross-site information } \\
\text { comparison and security and } \\
\text { privacy }\end{array}$ & $\begin{array}{l}\text { Design implications for consumer interface. Value of } \\
\text { interpersonal interaction in developing trust. }\end{array}$ \\
\hline Clarke (2006) & $\begin{array}{l}\text { Use of systemic functional } \\
\text { linguistics to analyze workplace } \\
\text { activities and practices }\end{array}$ & $\begin{array}{l}\text { Analysis of information exchanges between individuals } \\
\text { engaged in a process enables definition of canonical } \\
\text { genres of communication }\end{array}$ \\
\hline $\begin{array}{l}\text { Eighmy and } \\
\text { McCord (1998) }\end{array}$ & $\begin{array}{l}\text { Websites use and consumer } \\
\text { gratification, similarities to other } \\
\text { media and need for continued } \\
\text { relationship and personal } \\
\text { involvement }\end{array}$ & $\begin{array}{l}\text { Importance of entertainment and personal involvement in } \\
\text { continued online customer relationships and purchase } \\
\text { intent. }\end{array}$ \\
\hline Klein (1998) & $\begin{array}{l}\text { Internet search behaviour } \\
\text { differences between search and } \\
\text { experience products based on } \\
\text { economics and media attributes }\end{array}$ & $\begin{array}{l}\text { Importance of vicarious experience and/or trial for } \\
\text { managing higher perceived risk online. Potential to add } \\
\text { consumer value with information. }\end{array}$ \\
\hline Kozinets (2002) & $\begin{array}{l}\text { Validity of netnography as a } \\
\text { research method }\end{array}$ & $\begin{array}{l}\text { As a form on online ethnography, netnography is more } \\
\text { naturalistic and less intrusive than offline methods such } \\
\text { as focus groups. Newsgroup posters are characterized as } \\
\text { highly involved and innovative or classic lead users for a } \\
\text { product. Analysis of exchanges offers deep insights into } \\
\text { product meaning, positioning, purchase behaviour, } \\
\text { motivation, linguistic conventions and symbolism. }\end{array}$ \\
\hline Kozinets (2006) & $\begin{array}{l}\text { Update on applications of } \\
\text { netnography. }\end{array}$ & $\begin{array}{l}\text { Potential of netnography to address many different } \\
\text { research problems and application to more recent online } \\
\text { applications including blogs, instant messaging and } \\
\text { MMOG (massively multiplayer online games). }\end{array}$ \\
\hline $\begin{array}{l}\text { McGaughey and } \\
\text { Mason (1998) }\end{array}$ & $\begin{array}{l}\text { Internet influence on buyer } \\
\text { behaviour through buying process }\end{array}$ & $\begin{array}{l}\text { Role of interaction options for building dialogue with } \\
\text { consumers online. }\end{array}$ \\
\hline $\begin{array}{l}\text { Peterson and } \\
\text { Merino (2003) }\end{array}$ & $\begin{array}{l}\text { Limitations of internet utility. } \\
\text { Need for research focus on } \\
\text { moderators and interactions of } \\
\text { search behaviours. }\end{array}$ & $\begin{array}{l}\text { Key moderators proposed as consumer characteristics, } \\
\text { type of information sought, product characteristics, } \\
\text { search motivation and sources used. Consumer product } \\
\text { knowledge level a key factor. }\end{array}$ \\
\hline
\end{tabular}

Table 4: Literature relating to consumer expression as data

Firstly Kozinets (2006) has shown that linguistic analysis of online forum text enables socio-

semiotic definition of individuals and groups, enabling classification of such groups within a

target market. Kozinets coined the term "netnography" to reflect the insights into consumer need

Page | 23 
differences that may be drawn from analysis of such text inputs. The unique expression of interests within such groups may offer an alternative way to deal with product and personal factor complexity based on behavioural and/or value in use segmentation. In using the data in this way, the consumer's value structures or behavioural tendencies are taken as a synthesis of personality and other long term personal trait factors that are otherwise difficult to discern. Together with indicators of transitory state factors, induced from variance from clickstream behavioural patterns, such text analysis may offer useful insights into real time customer needs.

Secondly, online text input analysis offers superior insights into consumer needs than focus groups and depth interviews (Kozinets, 2002) and may form an additional use of such data. Linguistic and semantic analysis of an individual's entries in an online forum or in text queries may therefore offer clues to changes in need reflecting real time reactions to information on the website or drawn from elsewhere. Strong linguistic and role conventions have been identified within online forums (Bagozzi and Dholakia, 2002) so structural and lexicographic analysis of text may identify key words and phrases with particular meaning. The words or sentence structure used by a consumer in an identified group should indicate rational and emotional responses to content and satisfaction or frustration with implications for further information needs. As well as offering an additional source of insight into deviation from behavioural norms by consumers, suggesting a change in situation and need, such communication analysis offers an understanding of the effect of information viewed by a consumer. Social semiotic communication models can identify affective responses associated with decision making activities based on analysis of analyst-user interviews to identify relevant protocols (Clarke, 2006). The vendor's system for content serving may then be programmed for delivery of relevant website content or links to other sites based on the consumer's real time need or situation. 
Thirdly, conformity with online forum conventions is associated with high levels of trust (Bickart and Schindler, 2001; Bagozzi and Dholakia, 2002) within online forums. Adhering to such conventions may offer a remedy for the lack of personal interaction that frustrates consumers online. This represents a major advance in overcoming a serious utility deficiency of online information service based on the impersonal nature of online communication (Eighmy and McCord, 1998; McGaughey and Mason, 1998; Klein, 1998; Brown and Sellen, 2001; Peterson and Merino, 2003). The key to achieving this is found in moving from what Brown and Duguid (2000, p 21) term "overreliance on information", or what is offered, to considering the effects or communication resulting from the information. While such an approach does not approximate human or even artificial intelligence, it moves a lot closer to achieving a responsive dialogue with a consumer on a website than current practice.

\section{SUMMARY}

This review of current literature dealing with online consumer information search behaviour shows that none of these streams of research is self sufficient in explaining likely online consumer activity. To achieve a dynamic and responsive online information service with cognitive lock-in benefits, based on an evolving understanding of the consumer's needs in real time, an integration of all types of data is likely to be needed. In this scenario clickstream data offers real time data with an ability to identify patterns of behaviour within and between browsing sessions. As Moe (2003) did, clickstream data patterns can be augmented with other data releasing the heterogeneous model condition and offering insights into consumer motivation beyond information search objectives. Such data, derived from analysing of customer text expression online in forums and/or online queries and patterns of content specific clickstream data offers pointers to individual product and personal factors. The resulting insights into consumer needs could then be combined with heuristic behavioural patterns reflecting roles and utility trade-offs associated with various information types and formats online for consumer Page 125 
information search. Based on this the consumer may be served with far more reliable offerings of online information sources either within the website or through links to alternative information sources. Before this can be done however, a range of knowledge gaps must be addressed for implementing modelling of the type proposed in this paper. There are also a number of operational considerations that have to be addressed for such a system to be used to best possible effect.

\subsection{Knowledge gaps}

Research is required in two principal areas, first to identify behavioural typologies and the underlying motivation behind adherence to an established pattern and the meaning of deviations from established patterns. Second an understanding of the roles of information source types, formats online and offline and the characteristics of information that collectively meets a consumer's purchase process needs is required. This may be done for a specific product through a phenomenological study of consumers that monitors their click behaviour and language use while probing for reasons or motivation that underlies the behaviour. The protocol analysis used for identifying the basis of language use would have to address communicative, functional, semantic and contextual aspects of consumer purchase activity (Grant et al., 2010).

The analysis could be based on Halliday's (1978) communication theory which has been adapted by management researchers (Halliday and Hasan, 1985; Martin, 1992; Clarke, 2006) to analyse processes within organisations. Such analysis offers insights into process needs and likely sequencing of activities that follow to satisfy both emotional needs and functional needs. Functional aspects draw on social semiotics to examine the relationship between communication form and pattern and the environment or society in which it is used to develop understanding of meaning within a community. Semantic aspects offer the prospect of identifying situations based on specific language (register) and the use of vocabulary as an indicator of product knowledge Page 126 
levels. Such semantics also offer the potential for developing typologies of behaviour to extend the clickstream data offering a basis for triangulation to specify consumer needs. Finally, context has to be addressed in terms of situation to determine social actions and activities and cultural patterns of activity within a given community of interest. The detail of this methodology is however beyond the scope of this paper.

\subsection{Operational considerations}

Online marketing operational practices for organisations wishing to use such modelling practices for reliable and effective information serving may require greater recognition of the value added by third parties to consumer purchase process needs. At the very least this requires identification of online information source types and formats that meet the consumer's need and may be offered in the form of a link to the relevant web page. This may satisfy any one of a number of needs for the consumer from an independent information source in a preferred format for validating understanding, a complementary product or service or even a referral to a local purchase point. Ideally however, such arrangements may progress to the level of a network of alliance partners where each has a distinctive and well understood role in meeting the consumer's needs. A possible basis for such an alliance network could be a mutual dependency on a central shared server which models consumer activity and serves information that meets their needs as they progress through a purchase process. Such a central server could also be the location of chat rooms and forums that encourage consumers to interact with each other and generate data that offers insights into their needs in real time. This shared resource would also offer the benefit of higher engagement with consumers and the attendant positive purchase behaviours identified by Bickart and Schindler (2001).

Finally, the ability of such a modelling system to serve relevant information in real time to consumers seems likely to result in high levels of cognitive lock-in (Murray and Häubl, 2007). Page 127 
The resultant selection of a website by a consumer as a resource of first choice is an indispensible foundation stone to a customer-supplier relationship. It also offers communication benefits in a higher level of engagement (Calder and Malthouse, 2008) which, as identified in the introduction to the paper, facilitate complexity management and information service quality. As Bolton and Saxena-Iyer (2009) show this results in reduced consumer search costs, lower price sensitivity and increased hedonic indulgence for consumers. Perhaps the key challenge in this however is the need for vendors to move away from thinking of the internet as a way to reach consumers direct and effect disintermediation. Instead the approach should be one of connecting multiple resources for mutual gain through making the internet a far more rewarding resource for consumers by serving appropriate information source types and formats as they move through their purchase process.

\section{REFERENCES}

Bagozzi, R. P. and Dholakia U. M. (2002) "Intentional Social Action in Virtual Communities" Journal of Interactive Marketing, Vol 16, No 2, Spring 2002, pp 2 - 21

Bettman, J. R., Johnson, E. J. and Payne, J. W. (1991) “Consumer Decision Making,” in Handbook of Consumer Behaviour, eds. Robertson T. S. and Kassarjian, H. H., Prentice Hall, Englewood Cliffs, N.J.

Bickart, B. and Schindler R. M. (2001) "Internet Forums as Influential Sources of Consumer Information” Journal of Interactive Marketing, Vol 15, No 3, Summer 2001, pp 31 - 40

Bolton, R. N. and Saxena_Iyer, S. (2009), “Interactive Services: A Framework, Synthesis and Research Directions," Journal of Interactive Marketing, Vol 23, February 2009, pp 91 - 104

Brown, J. S. and Duguid, P (2000) The Social Life of Information, J. Seely Brown and Paul Duguid, Harvard Business School Press, Boston Mass. 2000.

Brown, B. and Sellen A. (2001) "Exploring Users' Experiences on the Web," First Monday, Volume 6, No 9, September 2001.

Page | 28 
Caccioppo, J. T., Petty, R. E., Feinstein, J. A. and Jarvis W. G. J. (1996) “Dispositional Differences in Cognitive Motivation: The Life and Times of Individuals Varying in Need for Cognition,” Psychological Bulletin, Vol 119, No 2, pp 197 - 253

Calder, B. J. And Malthouse, E. C. (2008) "Media engagement and advertising effectiveness," in Kellogg on Advertising and Media, ed. B. J. Calder, John Wiley and Sons, Hoboken, NJ, 2008

Chatterjee, P.; Hoffman, D. P. and Novak, T. P. (2003) "Modelling the clickstream: Implications for web based advertising efforts," Marketing Science, Vol 22, No 4, Fall 2003, pp 520 - 541

Clarke, R. J. (2006) “The Work that Analysts Do: A Systemic Functional Approach to Elicitation," in Nilsson, A. G.; Gustas, R.; Wojtkowski, W.; Wojtkowski, W. G.; Wrycza, S. and Zupančič (2006) Advances in Information Systems Development: Proceedings of the $14^{\text {th }}$ International Conference on Information Systems Development Bridging the Gap Between Academia and Industry, Vol 1 NY: Springer Science + Business Media ISBN - 10:0-38730834-2, pp $325-336$

Conchar, M. P., Zinkhan, G. M., Peters, C. and Olavarrieta, S. (2004) “An Integrated Framework for the Conceptualization of Consumers' Perceived Risk Processing," Academy of Marketing Science Journal, Vol 32, No 4, Fall 2004, pp 418 - 436

Day, G. S. (1998), “Organizing for Interactivity,” Journal of Interactive Marketing, Vol 12, No 1, Winter 1998, pp $47-54$

Degeratu, A. M., Rangaswamy, A. and Wu, J. (2000) “Consumer Choice Behaviour in Online and Traditional Supermarkets: The Effects of Brand Name, Price and Other Search Attributes," International Journal of Research in Marketing, Vol 17, 2000, pp 55 - 78

Eighmy and McCord (1998) “Adding Value in the Information Age: Uses and Gratifications of Sites on the World Wide Web," Journal of Business Research, Vol 41, 1998, pp 187 - 194 
Grant, R.; Clarke, R. J. and Kyriazis, E. (2010) "Research needs for assessing online value creation in complex consumer purchase process behaviour," Journal of Retailing and Consumer Services, Vol 17, No 1, pp 53 - 60

Grant, R.; Clarke, R. J. and Kyriazis, E. (2007) “A review of factors affecting online consumer search behaviour from an information value perspective," The Journal of Marketing Management, Vol 23, No 5-6, pp. 519 - 533

Halliday, M. A. K. (1978) Language as Social Semiotic: The social interpretation of language and meaning, Edward Arnold, Great Britain.

Hassan, R. (1985) “The structure of a text,” in Halliday, M.A.K. and Hasan, R. Language, Context and Text: Aspects of Language in a Social Semiotic Perspective, Deakin University Press, Geelong, Victoria.

Hill, D. (2001) “Tell me no lies: Using science to connect with consumers," Journal of Interactive Marketing, Vol 17, No 4, Autumn 2003, pp 61 - 72

Jensen, T., Kees, J., Burton, S. and Turnipseed F. L. (2003) “Advertised Reference Prices in an Internet Environment: Effects on Consumer Price Perceptions and Channel Search Intentions," Journal of Interactive Marketing, Vol 17, No 2, Spring 2003, pp 20 - 33

Johnson E. J., Bellman S. and Lohse G. L. (2003) "Cognitive lock in and the power of practice," Journal of Marketing, Vol 67, No 2, Apr 2003, pp 62 - 75

Johnson, E. J., Moe, W. W., Fader, P. S., Bellman, S. and Lohse, G. L. (2004) “On the Depth and Dynamics of Search Behaviour,” Management Science, Vol 50, Iss 3, March 2004, pp 299 308

Jones, M. Y., Pentecost, R. and Requena, G. (2005), "Memory for advertising and information content: Comparing the printed page to the computer screen," Psychology \& Marketing, Vol 22, No 8, August 2005, pp $623-648$

Klein, L. (1998) "Evaluating the Potential of Interactive Media Through a New Lens: Search versus Experience Goods,” Journal of Business Research, Vol 41, pp 195 - 203 
Klein, L. R. (2003), “Creating virtual product experiences: The role of telepresence,” Journal of Interactive Marketing, Vol 17, No 1, Winter 2003, pp 41 - 55

Klein, L. R. and Ford, G. T. (2003) "Consumer search for information in the digital age: An empirical study of prepurchase search for automobiles," Journal of interactive Marketing, Vol 17, No 3, Summer 2003, pp $29-49$

Kozinets, R. V. (2002) “The Field Behind the Screen: Using Netnography for Marketing Research in Online Communities," Journal of Marketing Research, Vol XXXIX, No 1, February 2002, pp $61-72$

Kozinets, R. V. (2006) “Netnography 2.0,” In Handbook of Qualitative Research Methods in Marketing, Ed Russell W. Belk, Edward Elgar, Cheltenham, UK.

Lee, B-K. and Lee W-N. (2004) "The Effect of Information Overload on Consumer Choice Quality in an On-Line Environment," Psychology \& Marketing, Vol 21, No 3, March 2004, pp $159-183$

Li, H., Daugherty, T. and Biocca, F. (2001), "Characteristics of virtual experience in electronic commerce: A protocol analysis," Journal of Interactive Marketing, Vol 15, No 3, Summer 2001, pp $13-30$

Lohse, G. L., Bellman, S. and Johnson E. J. (2000) “Consumer Buying on the Internet: Findings from Panel Data," Journal of Interactive Marketing, Winter 2000, Vol 14, No 1, pp 15 - 29

Martin, J. R. (1992) English Text: System and Structure, John Benjamins, Amsterdam

McGaughey, R. E. and Mason, K. H. (1998) “The internet as a marketing tool,” Journal of Marketing Theory and Practice, Vol 6, No 3, Summer 1998, pp 1 - 11

Moe, W. W. (2003) "Buying, Searching or Browsing: Differentiating Between Online Shoppers Using In-Store Navigational Clickstreams,” Journal of Consumer Psychology, Vol 13 No’s 1 $\& 2, \operatorname{pp} 29-40$ 
Moon, B-J. (2004) "Consumer Adoption of the Internet as an Information Search and Product Purchase Channel: Some Research Hypotheses,” International Journal of Internet Marketing and Advertising, Vol 1, No 1, 2004, pp $104-118$

Murray, K. B., \& Häubl, G. (2007). "Explaining Cognitive Lock-in: The Role of Skill-based Habits of Use in Consumer Choice," Journal of Consumer Research, Vol 34, No 1, June 2007, pp. $77-88$

Park, Y-H. and Fader, P. S. (2004), "Modelling browsing behaviour at multiple websites," Marketing Science, Vol 23, No 3, Summer 2004, pp 280 - 303

Peterson, R. A. and Merino M. C., (2003) "Consumer Information Search and the Internet" Psychology and Marketing February 2003 Vol 20, No 2, pp 99 - 121

Ratchford, B. T., Lee, M-S. and Talukdar, D, (2003) “The Impact of the Internet on Information Search for Automobiles," Journal of Marketing Research, Vol XL (May 2003) pp 193-209

Redmond, W. H. (2002) “The Potential Impact of Artificial Shopping Agents in E-Commerce Markets," Journal of Interactive Marketing, Vol 16, No 1, Winter 2002, pp 56 - 66

Richard, M-O. and Chandra R. (2005) “A Model of Web Navigational Behaviour: Conceptual Development and Application,” Journal of Business Research, Vol 56, 2005, pp 1019 - 1029

Steenkamp, J-B. E. M. and Baumgartner, H. (1992) “The Role of Optimum Stimulation Level in Exploratory Consumer Behaviour," Journal of Consumer Research, Vol 19, No 3, December 1992, pp $434-448$

Ylikoski, T. (2005), “A sequence analysis of consumers' online searches,” Internet Research, Vol 15 , No 2, pp $181-194$

Yoon S-J. and Kim J-H. (2001), "Is the internet more effective than traditional media? Factors affecting the choice of media," Journal of Advertising Research, Vol 41, No 6, Nov 2001, p 53 